\title{
Borderline Lesion
}

National Cancer Institute

\section{Source}

National Cancer Institute. Borderline Lesion. NCI Thesaurus. Code C36116.

A lesion characterized by the presence of atypical or low-grade neoplastic cells, which may or may not exhibit stromal microinvasion and cannot be qualified as completely malignant. 